\title{
The correlation between the development of human resource in education and the Romanian economy
}

\author{
Daniela-Roxana Pintilie, ,Al. I. Cuza” University of Iasi, Romania \\ Ciprian-Constantin Pintilie, „Al. I. Cuza” University of Iasi, Elitec, Romania \\ Andreea-Monica Chelu, „Al. I. Cuza” University of Iasi, Elitec, Romania
}

\begin{abstract}
This article is a thorough reflection on development of human resources and on influence they have programs career development of individual improvement. Representative data describe the impact of development programs on educational career. Education plays an essential role in the life of the individual both in terms of career, as well as economically. In this sense, the informations and the representative data which characterizes the Romanian educational system and ensure quality in education, are in important issue.
\end{abstract}

\section{Key Words}

Human resources management, sistem of education, management development, professional development, quality development, European trends.

\section{JEL Codes: M 12, I 21}

\section{Introduction}

Education plays a key role in an individual's life, both in terms of career, and the economic. Different business environments in which some people operate, regardless of the type of each environment, describing various events, events that reveal the intellectual training and value system in which each individual is located. Education (even at work) emphasize the individual in all circumstances and shall take precedence and ensure its success in any field in which he operates. The more education a person is better, the chances are higher and its prospects.

Education at work is called 'staff development'. Integrated often broad concept of 'training, professional development of human resources requires both training and acquisition of knowledge and skills and improve knowledge and skills already existing training and raising in relation to institutional change and / or existing functional active human resources company.

\section{Professional development of human resources in education}

The mission of any organization is to promote innovation and individual creativity to ensure the professional development of staff, whether individual or organizational groups. Educational institutions are considered by society models of innovation and change is expected to play key role in promoting economic, social, cultural.

Achieving excellence in education, training and research is the main factor that can ensure growth potential of the organization's human resources. As a result, human resource development is a necessary process, complex continuing and great responsibility, which involves concrete actions and activities of the new staff selection and training and retraining 
of the existing. Each educational institution in Romania is mainly responsible for educational services as training and professional development and quality assurance in education.

The term "professional development" can be defined as' a process that develops professional knowledge and skills necessary for effective professional practice. Hoyle's definition of this can come off the next issue: a professional must be able, independently one to decide what type of development work required.

Other authors define specialized 'staff development' in the context of education as "a systematic effort to harmonize their personal interests, desires and needs, carefully evaluated for further career development needs of the organization within which the person practicing . The two definitions lead to one conclusion, namely, that a close interdependence between institutional needs and individual needs. This interdependence leads to the development of educational institution personnel. Human Resources Development of the educational institution entails two aspects:

- concept, development management, namely training and development of teachers who have or have had responsibilities in the educational institution where they operate (Directors, Deputy Directors, Board members, heads of department etc.);

- should include all school personnel, both academic and non-teaching.

Staff development is seen not only as a chain of activities leading to performance, but can be regarded as a process. The term "process" includes: planning, training, work itself, training tracking (follow-up) and evaluation. Thus, the entire human resources development and training each component of the process must first be planned, implemented and evaluated by completing the following steps:

- adaptation of human resources development program in the school policy;

- development programs must be designed in accordance with the requirements of the high;

- ranking development process;

- identifying needs;

- establishing a work program and priorities within it;

- program implementation;

- monitoring and assessment program;

- the program review and identify future needs.

\section{Identifying professional development needs}

Ministry of Education, school inspectorates and schools can design a program to develop human resources according to individual or collective needs. In this respect needs to distinguish four types of underlying composition of a staff development program - national level:

- the strategy of reform of the Ministry of Education and Research in Education;

- local level: implementation priorities for reform and its implementation in the school inspectorates;

- the schools: priorities and policy development of each school unit which relies on human resources development program;

- individual level: individual development needs.

Priorities in education, according to the individual needs of teachers, are clearly stated. Education Reform in Romania to the following principles: decentralization of management, decongestion curricular flexibility and compatibility with European education systems and carried out in these directions: the mentality, structure and educational system. All these directions cause professional development needs.

Policy, strategies and priorities in education is an important source for generating human resources development needs. Each school has its educational policy. At school are allowed rules and principles, priorities and success by implementing a professional development program. It should be noted in this regard that each development program undertaken by the Ministry of Education is made free of charge for each frame in didactic. Regarding 
professional development programs other than those supported by the Ministry of Education, they are funded in part by each school.

People need to signal that they need development and will succeed only way to fulfill their assignments correctly and effectively, to increase career advancement opportunities or to improve their overall motivation. There must be development opportunities for teachers at every stage of their careers. Also, there is a need of implementation of development programs and teacher training, given the work of the school (classes that cover several areas and takes place at that school) or school centers (a work-related courses schools). Currently there is no system to detect general needs development / training, but they can be readily identified at each level schools through a questionnaire in which each teacher will complete. More questionnaires will be considered a guide to identify educational needs.

\section{Human resources development activities and their effectiveness}

In developing human resources in education may speak of the existence of activities and development programs and training of staff, both internal and external. As regards the internal development of the teaching staff can remember the following activities:

- mentoring ;

- activity in which a teacher, during a semester or school year dealing with a less experienced colleague professionally;

- rotation of duties;

- responsibilities are exchanged between teachers;

- additional responsibilities.

In respect to activities outside school, teachers are involved in working with colleagues from other schools, which entails the exchange of experience. The main purpose of staff development is to improve the educational process. Effectiveness of staff development not only training, but the unit where the development process must be conducted to see an improvement or change in career.

Effective professional development has the following characteristics:

- to consider the tasks directly related to the work of each teacher in part;

- development programs must include: theory, practice, demonstration, feedback and various applications in which the teacher is main participants;

- the follow-up (phase tracking) applications involving direct undergo teacher training;

- formal and non formal coordination between the elements;

- there is some link between training and certain elements of development process are subject to change process.

Professional development takes place throughout their lives as organized programs, both domestic and external, and ensure improved knowledge / skills that will enable individuals to operate in a most efficient and take pace with changes in institutional / functional appearing throughout your career.

Professional development of human resources is to develop professional ability of teachers to continue their growth and progress in institution.

HRD goal is to increase the capacity of a teacher to successfully perform duties and greater responsibilities, higher. Activities that help develop human resources are both internal and external, as mentioned above. They also include the internal and external development programs. Of activities within the institution can mention: activities directly related to function / job (eg, meditation, member of the teaching committee, depending on rotation, job assistance, training to carry out the responsibilities incumbent on the position held, etc.). and activities directly related to the function / job (eg, classroom training, psychological testing, training human resources, case studies, role playing, business games, etc.).

Necessary professional skills can be obtained through methods such as developing formal and nonformal. Formal methods most commonly used are: scientific conferences, national and international conferences, international mobility programs such as 'visiting professors' 
research projects, publishing activities and of non-formal methods can be mentioned: workshops, trainings, schools national and international summer etc.

To be highlighted methods involving human resource development in education level, a study research, highlighting the impact, contribution and importance of programs related to these methods, and connection that is established between these programs under development and population profile research process. The instrument, which was used in this research process is questionnaire. It covers:

- personnel policy pursued by St. Sava Kindergarten Science;

- researched population profile;

- the presentation of research needs of the population studied;

- analysis of professional development programs in Human resource education (both formal and informal);

- the importance and contribution of professional development programs.

The subjects of this research study has appealed to teachers of kindergarten St. Sava Iasi. The instrument of questionnaire used in this case is it being applied to 17 teachers: 3 beginner teachers, 4 teachers completed, 4 with grade 2 and 6 teachers in grade 1. For this research, the community chosen is structured as a single homogeneous subgroups characteristic ie academic degree held by each teacher. The questionnaire was applied directly investigated subjects engaged in actual area.

The questionnaire covers aspects of research focusing on:

- designing a general profile of the population studied, taking into account certain characteristics: age, gender, academic degree, etc.

- the importance of training programs in human resource development in education (in percent);

- the importance of training programs on human resources development process through data collected from subjects;

- sketched profile of the population studied correlation with the resulting analysis on the professional development of teachers of Kindergarten St. Sava Iasi.

Questionnaires were applied and completed by individual teachers. Subjects were anonymous said scientific and research. The research sample is based on the idea that training programs directly influences development of the school teachers investigated. Item has been taken into account regarding the influence programs the development of teacher training was, attending courses in the last 2 years. "From the research undertaken was noted that training programs influence subjects to participate in a low or high proportion, development courses, training and even training.

Kindergarten teachers work of St. Sava Science covers the following aspects:

- restructuring and improving staff training;

- management restructuring;

- changing organizational culture.

Undertaken the research to the development of teachers has the following objectives:

- to highlight the needs professional development of teachers;

- to explore professional development according to the methods underlying this development (formal and informal methods method);

- to highlight the importance and contribution development programs;

- to build a questionnaire based on certain criteria : gender, age, academic degree held by each teacher in the school under review, etc.).

Through this research aims to highlight the importance of the two methods, formal and nonformal, on professional development of teachers.

Stages of this research include the following:

- data collection through questionnaire;

- data processing - analysis of preliminary / final and their generalization.

Is an interdisciplinary research over the boundary of human resource management with service management and economics. This research is an explanatory in the sense that he 
proposes to achieve its objectives a priori, but to discover possible causal relationship between the concept of teacher professional development and impact of formal and non formal methods are incuring development on the one hand, and on other hand to highlight the importance of sustainable quality training as investment in the Romanian economy.

As conclusions from this research, to better illustrate the share of formal methods of professional development would analyze data according to two aspects:

- number of subjects combined annual participation;

- the number of annual participation of subjects, depending teaching degree.

\section{Human resource development in the Romanian economy}

Teacher participation in the process of training and specialization is one of the signs indicative of Romanian higher education, namely that the teacher education process aimed at speeding emphasis among students and so we can talk about quality in education. Bring further education benefit society. Assessing this aspect of economic, we can speak of a social return to education exceeds that individual. Human resource development is very important for an individual's personal ability to contribute to the economy and to earn more, but do not ignore the social consequences of the existence of a population with higher education levels. Teacher education and education of individuals in this case as the main subjects of the educational establishment to society many benefits, many of which have important effects on how the economy operates. Higher education may be associated with stability.

Teacher participation in the process of training and specialization is one of the signs indicative of Romanian higher education, namely that the teacher education process aimed at speeding emphasis among students and so we can talk about quality in education. Bring further education benefit society. Assessing this aspect of economic, we can speak of a social return to education exceeds that individual. Human resource development is very important for an individual's personal ability to contribute to the economy and to earn more, but do not ignore the social consequences of the existence of a population with higher education levels. Teacher education and education of individuals in this case as the main subjects of the educational establishment to society many benefits, many of which have important effects on how the economy operates. Higher education may be associated with stability.

\section{Conclusions}

Quality of training of human resources takes time, space and staff eager to meet high standards. European educational policy refers only title recommendations, the quality of training of teachers in European schools. Not incidentally, the main European processes, on the agenda of ministries of education (some bearing the original name of the cultural area in which they were discussed and approved, Lisbon, Bologna, Bergen) proposed that the priority strategic directions for teacher training and development.

System Development Romanian teachers faced with the absence or decrease the motivation of young graduates from universities for teaching career, with a limitation of perspective and a real feeling of risk. Teacher training system in terms of tradition involved a lot of positive aspects, factors of emotional support, of which we can remember what the teacher image and status are valued in the community and gradually diminished by insufficient financing, but the inconsistency of educational policy decisions. Although CVT is talking about consistency of processes and activities, however it is noted that professional development means regular training and that training by obtaining teaching degrees should not be ignored. Both must be harmoniously intertwine as two processes with different activities, but pursuing the same purpose - staff development in education. Staff development in education, in this case teachers, is played by those degrees and that each teacher education throughout his career he assumed (he claims) and to ensure the promotion. This is to increase the prestige of 
the teacher concerned (to be ranked as a good teacher), will increase the prestige of the school in which they operate and so, and parents guide their children to prestigious educational institution in training teachers. Hence the education institution that provides trained human capital market as the economy improves and the country. Professional development helps teachers to develop their economy or earnings.

\section{Bibliography}

1. Antonesei, L., (2005), Polis şi Paideia, Ed. Polirom, Iaşi.

2. Armstrong, M.,(1996), Personnel Management Practice, Kogan Page, Londra.

3. Birzea, C., Neacsu, I., Potolea, D., (2006), Educația şi formarea profesională a cadrelor didactice din România, research project Improving the professional development of the didactic staff and of the teaching practices - learning în south-eastern European contries, Open Society Institute, Bucharest.

4. Cucoş, C., (2002), Pedagogie, ediția a II-a, Ed. Polirom, Iaşi.

5. Everard, K.B., Morris Geoffrey,(1996), Effective School Management, ediția a treia, PCB, London.

6. Gavrilovici, O., Iosifescu, S., Prodan, A., (2004), Management educațional, vol II, The Romanian Institute for Education Management.

7. Ghergut, A., (2007), Management general şi strategic în educație, Polirom Publishing House, Iaşi.

8. Herman, J. Susan., (2008), Teaching Contemporany Human Resource Management, Journal of Management Education, aprilie, vol.32.

9. Manolescu, A., (2001), Managementul resurselor umane, Ed. Economică, Bucureşti.

10. Mathias, L. Robert., (1997), Managementul resurselor umane, Ed. Economică, Bucureşti.

11. Neculau, A.(coord.), (1997), Câmpul universitar şi actorii săi, Ed. Polirom, Iaşi.

12. Nica, P., Iftimescu, A., (2004), Management (concepte şi aplicații), Ed. Sedcom Libris, Iaşi.

13. Rotaru, A., Prodan, A., (2005), Managementul resurselor umane, Ed. Sedcom Libris, Iaşi.

14. Suciu, M. C., (2005), Investiția în educație, Ed. Economică, Bucureşti.

15. Warren, D. Piper., (1978)," Flexibility with control: an example of classroom contact and some other attempts to increase effectiveness", The efficiency and effectiveness of teaching în Higher education, ed. în Warren Piper, University of London Teaching Methods Unit.

16. *** UNESCO, (1998), "World Declaration on Higher Education for the Twenty-first Century:

Vision and Action and Framewprk for Priority Action for Change and Development în Higher Education", adoptes by the World Conference on Higher Education, October 9. 